\section{Failure of ranitidine to interact with propranolol}

The histamine $\mathrm{H}_{2}$-receptor antagonist ranitidine has recently been introduced into clinical practice for the treatment of peptic ulcer. Its therapeutic effects appear similar to those of cimetidine, but early reports suggest that it does not affect hepatic drug metabolism. ${ }^{12}$ This probably reflects a change in chemical structure, in that the central imidazole ring has been replaced by a furan ring and the sidechain has been modified. It has been suggested that the imidazole ring facilitates binding of cimetidine to microsomal cytochrome P450, ${ }^{3}$ which possibly explains the reduction in hepatic extraction of propranolol. It seems likely therefore that this would not be seen with ranitidine and we undertook a study to assess the effect of ranitidine on propranolol.

\section{Methods and results}

We studied six healthy volunteers (five men and one woman; average age 41 years, range 22-71). Two had taken part in a previous study of the interaction between cimetidine and propranolol, 4 All were non-smokers and had no evidence of respiratory, cardiovascular, renal, or thyroid disease. All gave informed consent and local ethical committee approval was obtained for the study. During the study no other drugs were allowed.

After an overnight fast $80 \mathrm{mg}$ propranolol was given orally and $5 \mathrm{ml}$ samples of venous blood were taken at $0,30,60,90,120,240,360,480$, and 720 minutes for estimating propranolol concentration. The study was repeated after a two-week course of ranitidine, $150 \mathrm{mg}$ orally twice daily; during this course a separate $10 \mathrm{ml}$ blood sample was taken for measuring plasma ranitidine concentrations, thereby ensuring compliance. After three weeks with no treatment four subjects took cimetidine $200 \mathrm{mg}$ orally three times daily and $400 \mathrm{mg}$ at night for two weeks, after which the study was repeated again. The other two subjects had taken cimetidine in a previous study. ${ }^{4}$

All blood samples were stored at $-20^{\circ} \mathrm{C}$ until assayed. Whole-blood propranolol concentrations were estimated using the fluorometric method previously described. ${ }^{4}$

The areas under the blood concentration time curves for propranolol with and without ranitidine were measured using a planimeter, and the values were used as a measure of the relative bioavailability of the drug. Data on ranitidine, cimetidine, and no treatment were compared using Student's $t$ test for paired data.

The figure shows mean blood propranolol concentrations with and without treatment. The data on cimetidine are included for comparison only as similar data have been reported previously. ${ }^{4}$

There was no significant difference between values with and without ranitidine at any time. There was also no significant difference between the mean area under the blood concentration time curve on ranitidine (328.4 $48 \cdot 8 \mu \mathrm{g} / 1 \mathrm{~h})$ and off it $(304 \cdot 3 \pm 42 \cdot 1 \mu \mathrm{g} / \mathrm{l} \mathrm{h})$.

\section{Comment}

These results show that ranitidine, unlike cimetidine, fails to affect the pharmacokinetics of propranolol after oral administration. Cimetidine almost certainly affects the hepatic handling of drugs by binding to microsomal enzymes and there seems little doubt that the difference in interference with drug metabolism between ranitidine and cimetidine is attributable to structural anomalies. It seems likely,

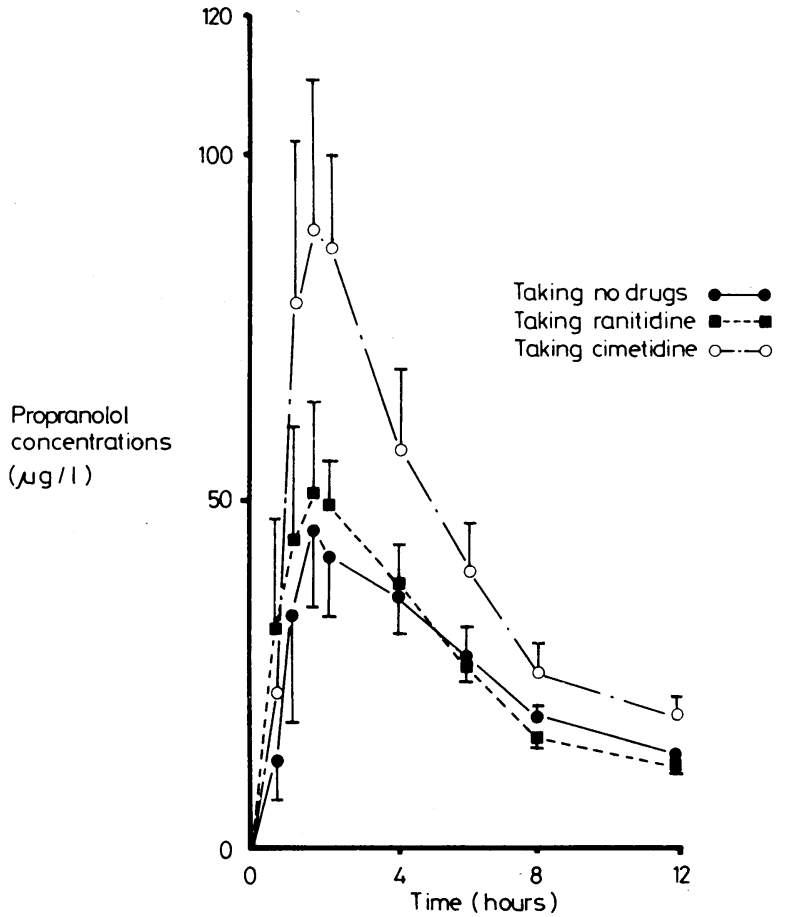

Mean \pm SEM blood propranolol concentrations against time.

therefore, that ranitidine will not change the hepatic handling of other drugs already shown to be influenced by cimetidine. ${ }^{45}$

${ }^{1}$ Henry DA, Macdonald IA, Kitchingman G, Bell GD, Langman MJS. Cimetidine and ranitidine: comparison of effects on hepatic drug metabolism. $\mathrm{Br} \mathrm{Med} \mathcal{F} 1980 ; 280: 775-7$.

2 Serlin MJ, Sibeon RG, Breckonridge AM. Lack of effect of ranitidine on warfarin action. Br $\mathcal{F}$ Clin Pharmacol 1981;12:791-5.

${ }^{3}$ Rendic S, Sunjic V, Toso R, Kaiffez F, Ruf HH. Interaction of cimetidine with liver microsomes. Xenobiotica 1979;9:555-64.

${ }^{4}$ Heagerty AM, Donovan MA, Castleden CM, Pohl JF, Patel L, Hedges A. Influence of cimetidine on pharmacokinetics of propranolol. $\mathrm{Br} \mathrm{Med} \mathcal{F}$ 1981 ;282:1917-9.

${ }^{5}$ Betzel DJ, Bochner F, Hallpike JF, Shearman DJC, Hann CS. Cimetidine interaction with phenytoin. $\mathrm{Br}$ Med $\mathcal{F} 1981$;282:1512.

(Accepted 11 February 1982)

Department of Medicine, University of Leicester, Leicester LE2 7LX

A M HEAGERTY, MB, MRCP, medical registrar

C M CASTLEDEN, MD, MRCP, senior lecturer in geriatric medicine

Department of Clinical Pharmacology, St Bartholomew's Hospital, London EC1A 7BE

L PATEL, BSC, research assistant
MEDICINES APPROPRIATED TO THE SPLEEN-In the breeding of blood, are three excrements most conspicuous, viz urine, choler, and melancholy. The proper seat of choler is in the gall. The urine passeth down to the reins or kidneys, which is all one. The spleen takes the thickest or melancholy blood to itself. This excrement of blood is twofold: for either by excessive heat, it is addust, and this is that the Latins call Atra Bilis: or else it is thick and earthly of itself, and this properly is called melancholy humour. Hence then is the nature of splenical medicines to be found out, and by these two is the spleen usually afflicted for Atra bilis (I know not what distinct English name to give it), many times causes madness, and pure melancholy causeth obstructions of the bowels, and tumours, whereby the concoction of the blood is vitiated, and dropsies many times follow. Medicines then peculiar to the spleen must needs be twofold also, some appropriated to Atra bilis, others to pure melancholy; but of purging either of them, I shall omit till I come to treat of purging in a chapter by itself. 1 . Such medicines are splenical, which by cooling and moistening temper Atra bilis: let not these medicines be too cold neither, for there is no such heat in Atra bilis as there is in choler, and therefore it needs no such excessive cooling: amongst the number of these are such as we mentioned amongst the cordials to repel melancholy vapours from the heart, such temper and assuage the malice of Atra bilis. 2. Those medicines are also splenical, by which melancholy humours are corrected and so prepared, that they may the more easily be evacuated: such medicines are cutting and opening, and they differ from hepaticals in this that they are no ways binding; for the spleen being no ways addicted to concoction, binding medicines do it harm, and not good. 3. Sometimes the spleen is not only obstructed, but also hardened by melancholy humours, and in such cases emolient medicines may be well called splenicals, not such as are taken inwardly, for they operate upon the stomach and bowels, but such as are outwardly applied to the region of the spleen.

And although sometimes medicines, are outwardly applied to hardness of the liver, yet they differ from splenicals, because they are binding, so are not splenicals. (Nicholas Culpeper (1616-54) The Complete Herbal, 1850.) 